\title{
THE PETERSON LIMESTONE - EARLY CRETACEOUS LACUSTRINE CARBONATE DEPOSITION IN WESTERN WYOMING AND SOUTHEASTERN IDAHO
}

\author{
STEVEN W. GLASS and BRUCE H. WILKINSON \\ Department of Geology and Mineralogy, The University of Michigan, Ann Arbor, Mich. \\ 48109 (U.S.A.)
}

(Received May 1, 1979; revised and accepted December 3, 1979)

\begin{abstract}
ABSTRAC'T
Glass, S.W. and Wilkinson, B.H., 1980. The Peterson Limestone - Early Cretaceous lacustrine carbonate deposition in western Wyoming and southeastern Idaho. Sediment. Geol., 27: 143-160.
\end{abstract}

The lacustrine Peterson Limestone of western Wyoming and southeastern Idaho comprises six lithofacies throughout its $20,000 \mathrm{~km}^{2}$ aerial extent. These are: (1) calcareous sandstone and shale, (2) red nodular limestone, (3) pink sandy micrite, (4) biomicrite, (5) graded silty micrite, and (6) limestone conglomerate. The first two represent floodplain deposition and paleosols, whereas the remaining are shallow nearshore and deeper lacustrine sediments.

This sequence was developed in a large fresh, hardwater lake surrounded by fluvial systems and associated flood plains in a warm temperate climate. Well-oxidized sandy terrigenous rocks, together with calcareous paleosol nodules, indicate that flood-plain deposition both preceded and was concurrent with lacustrine carbonate deposition. Micrite and biomicrite formed in deeper parts of the basin while sandy and silty carbonate accumulated in shallower lake-margin areas. Less-calcareous shale units which are interbedded with deeper-water carbonate were deposited either during rapid basin subsidence and deepening of the lake center or during periods of slower carbonate precipitation. Turbidity currents and subaqueous debris flows generated along steeper lake margins, resulted in the deposition of rhythmic layers of graded silty micrite and diamictic limestone conglomerate in the deepest part of the basin. The carbonate-rich sediments comprising these two lithofacies were originally deposited on shallow lake-margin benches and subsequently were transported downslope toward the lake center.

Comparison with other carbonate-precipitating lacustrine systems indicates that this lake was not like modern playas. Although no known modern lacustrine system is precisely like Lake Peterson, the flora, fauna, composition, and distribution of facies within modern temperate-region lakes most closely resemble those of the Peterson Limestone.

\section{INTRODUCTION}

Although lacustrine carbonates are nearly ubiquitous in ancient continental sections, and may constitute a significant part of these sequences, the 
processes responsible for lacustrine carbonate deposition are poorly known. The Early Cretaceous Peterson Limestone is an example of such a deposit, and affords opportunity for the detailed study of ancient lacustrine processes. While lithologic variation within ancient lake systems is often large, both the excellent exposure and fabric preservation typical of this unit permit a detailed interpretation of its component facies.

The Peterson Limestone is one of five formations comprising the nonmarine Upper Jurassic-Lower Cretaceous Gannett Group which is well exposed throughout western Wyoming and southeastern Idaho (Mansfield and Roundy, 1916; Love et al., 1948; Love, 1956) (Fig. 1). These were deposited in a south-trending structural basin which migrated eastward throughout the Mesozoic, but was centered several kilometers west of the Wyoming-Idaho border during deposition of the Peterson Limestone (Armstrong and Oriel, 1965). Deposition of the Gannett Group followed regression of a Late Jurassic epicontinental sea during the earliest stages of the Laramide orogeny and ended with transgression of the Cretaceous western interior sea, which then controlled major patterns of sedimentation (Kauffman, 1977). The Gannett Group is thickest along the Idaho-Wyoming line where approximately one kilometer of rock is preserved. Terrigenous formations within the Gannett Group are: the Ephriam Conglomerate, the Bechler Sandstone, and the Smoot Shale, which are separated in vertical succession by the Peterson and Draney limestones. The lower part of the Ephriam is latest Jurassic in age, whereas Aptian floras and faunas are present in the Peterson Limestone (Eyer, 1964, 1969). The Smoot spans the Aptian-Albian boundary. The noncarbonate siliciclastic formations represent synorogenic deposition associated with denudation of Paleozoic formations that were elevated in eastern Idaho during thrusting on the Paris fault, the earliest and westernmost fault in the Overthrust Belt (Fig. 1). Sediments shed off this block were transported eastward, as indicated by a decreasing of grain size and a thinning of deposits in that direction. Each of the three terrigenous formations possibly resulted from separate episodic movements on the thrust, while slow subsidence, lake development, and associated deposition of the Peterson and Draney limestones occurred during periods of tectonic quiescence when little terrigenous material was transported basinward. Alternatively, these lake basins may have developed during periods of rapid basin subsidence, unrelated to temporal variations in fault movements or rates of terrigenous influx.

The Ephriam and Bechler formations, which, respectively, underlie and overlie the Peterson Limestone, were deposited by fluvial processes as indicated by an abundance of channel-fill conglomerates and cross-bedded sandstones. Finer-grained calcareous shales and mudstones represent floodplain sediments associated with these fluvial systems. They are mottled, oxidized, burrowed, and represent, in part, paleosol horizons. The stratigraphic succession from the Ephriam through the Peterson Limestone and up into Bechler rock units represents a transgressive-regressive lacustrine 


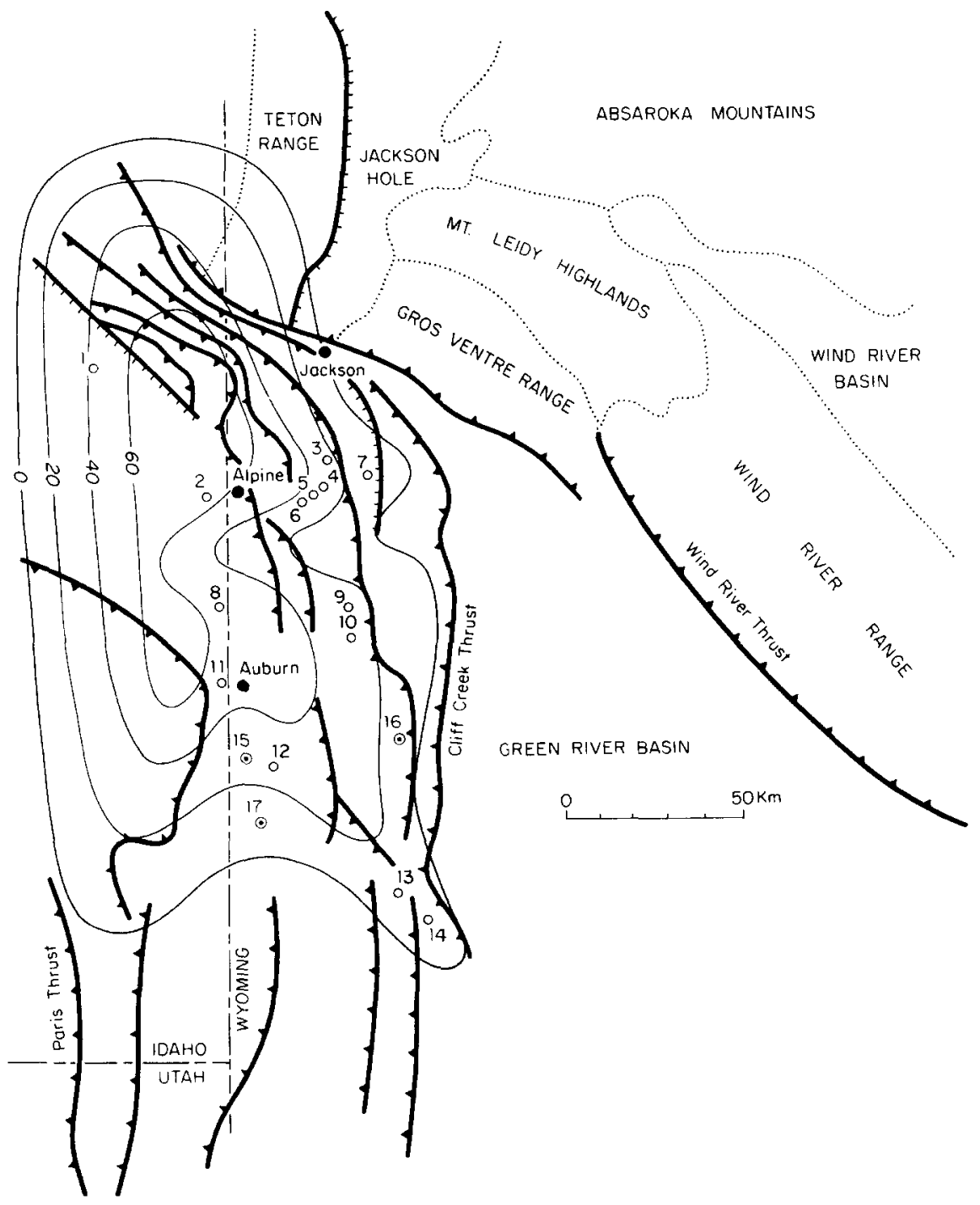

Fig. 1. Index map of western Wyoming and southeastern Idaho, and isopach map of the Peterson Limestone. Note the major tectonic elements of the region and the location of 17 measured stratigraphic sections of the Peterson Limestone. Open circles are data from this study; dotted circles are thickness data from Eyer (1964). Isopach data are in meters.

sequence that resulted from deposition of fluvial flood-plain and then lacustrine units, followed by renewed fluvial and flood-plain sedimentation.

\section{GENERAL SETTING}

The lacustrine Peterson Limestone is well exposed within the Overthrust Belt, where it attains a maximum thickness of $70 \mathrm{~m}$ just west of the Wyom- 

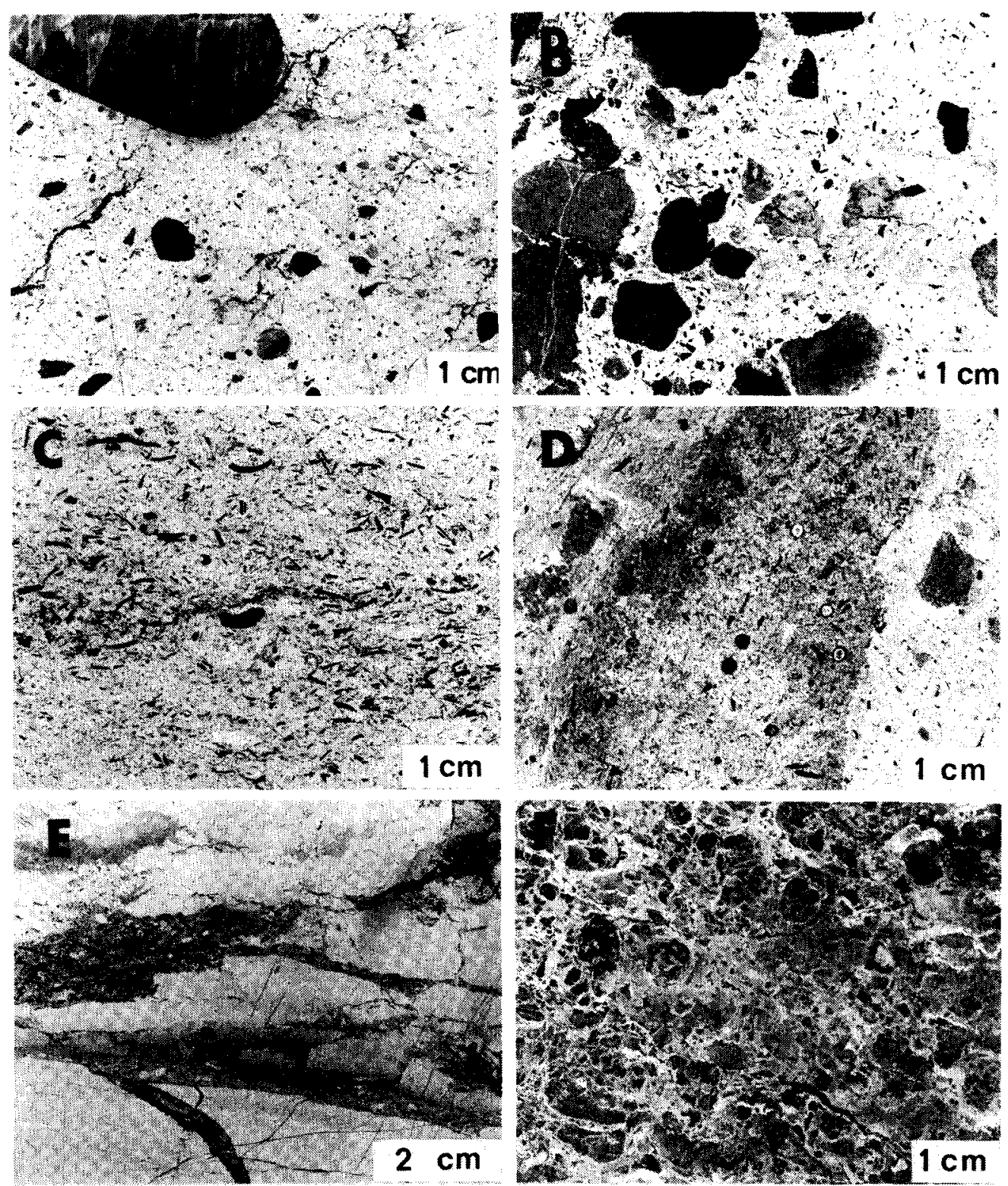

Fig. 2. Etched slabs of three characteristic Peterson Limestone facies.

A. Limestone conglomerate with a large quartzite dropstone in the upper left. This and subsequent slabs have been lightly etched with dilute hydrochloric acid to accentuate their fabric. Lithologies containing abundant diagenetic microcrystalline silica appear lighter, whereas more calcitic areas are typically dark. Note several calcitic conglomerate clasts and the dropstone "floating" in more siliceous carbonate mudstone.

B. Coarse limestone conglomerate. Note that the calcitic clasts are unsorted, loosely packed, and randomly oriented. 
ing-Idaho border (Fig. 1). This large lens-shaped deposit is the only unit which occurs stratigraphically between the Ephriam and Bechler formations, suggesting that rather than a series of small separate basins, the lake in which the Peterson Limestone was deposited was a single body of water that covered a minimum area of approximately $20,000 \mathrm{~km}^{2}$. Nearly all facies within the Peterson are composed of significant fractions of calcite, dolomite, and microcrystalline quartz (Figs. 2 and 3). Dolomite occurs as fine-grained euhedral rhombs $(10-20 \mu)$ scattered throughout a surrounding matrix consisting of an interwoven meshwork of calcite and quartz (Holm, 1977). The matrix microfabric when completely leached of all carbonate with strong acid consists of a rigid framework of quartz intermeshed with anhedral calcite voids. After leaching, dolomite grains exist as rhombic molds (Fig. 3E, F).

Dolomitization preceded the formation of the three-dimensional quartz matrix, since rhombs are molded in this framework. The origin of the quartz is problematic. We conclude that its origin is diagenetic, similar to the formation of very calcareous dolomitic chert on a regional scale. Three possible sources of silica in this quartz matrix are: (1) silica-rich ground waters percolating through carbonate rocks after dolomitization, (2) opaline sponge spicules which have crystallized during diagenesis, and (3) volcanic glass which has crystallized during diagenesis. Volcanic glass can also alter to montmorillonite and chlorite, both of which are present in shaley units of the Peterson. Although conclusive evidence of volcanic ash has not been found in the Gannett Group, the coeval Morrison and Cloverly formations in the Bighorn Mountains to the east do contain bentonitic mudstones (Mirsky, 1962). Qualitative analysis of suites of Peterson samples indicate that the more calcitic limestones are more common in units stratigraphically high or stratigraphically low in a section. By inference, then, siliceous carbonates accumulated more extensively in the basin center than along basin margins.

C. Biomicrite with abundant molluscan and ostracodal shell debris. The small fragments of shells have a preferred orientation parallel to bedding. Again note the contrast between the dark calcite shells and the lighter siliceous carbonate matrix.

D. Biomicrite with abundant spherical spar-filled charophyte gyrogonites and broken-shell material. Biogenic allochems comprise approximately $25 \%$ of this sample, which is typical of the biomicrite facies.

E. Irregularly laminated biomicrite and relatively pure siliceous micrite. Note the ruptured appearance of the more micritic units. In this sample, fracturing and distortion of micritic beds is due to both bioturbation and soft-sediment compaction of semi-cohesive units.

F. Micrite nodule from the red nodular limestone facies. Brecciated micrite clasts are cemented with megaquartz, chalcedony and sparry calcite. Note the total absence of lacustrine fossils in this nodule, compared with $\mathrm{C}$ and $\mathrm{D}$. 

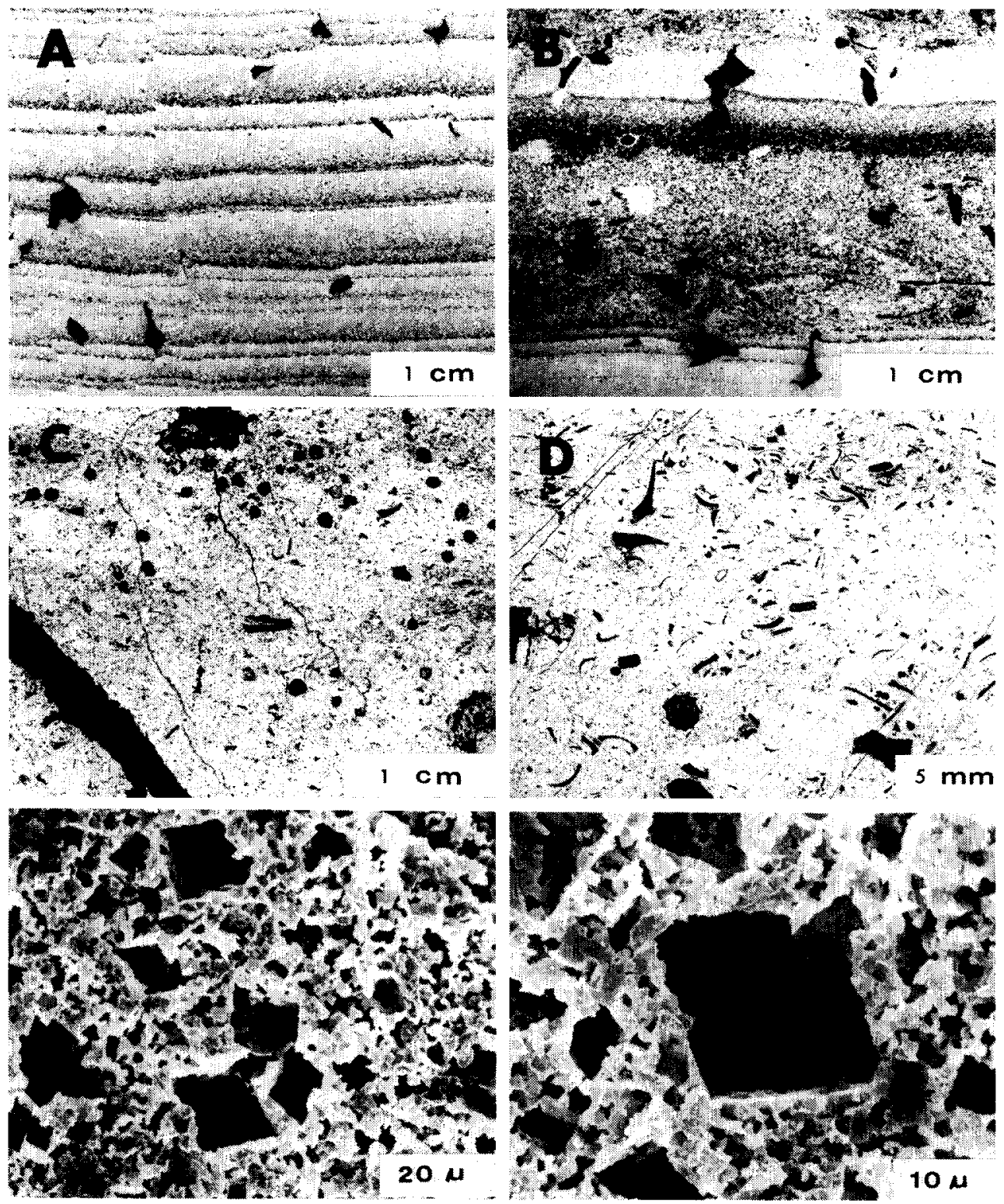

Fig. 3. Thin-section and scanning electron photomicrographs of several important rock types of the Peterson Limestone.

A. Thin-section of graded silty micrite. Individual laminations are composed of finingupward sequences, with terrigenous silt- and sand-sized quartz and feldspar concentrated in the base (darker portions) grading into siliceous carbonate mud in the top (lighter portions). Note sharp basal contacts, and numerous spar-filled vugs. The small reverse fault in the left side of the photograph dies out toward the base of the picture. Nineteen graded units are present in this field of view. 


\section{PETERSON LITHOFACIES}

The vertical distribution of lithofacies in the Peterson Formation strongly reflects the transgressive-regressive nature of the system. In a typical section, component facies are: (1) calcareous sandstone and shale, (2) red nodular limestone, (3) pink sandy micrite, (4) biomicrite, (5) graded silty micrite, and (6) limestone conglomerate (Figs. 2 and 3). Volumetrically, biomicrite is most important, comprising approximately $75 \%$ of the Peterson Limestone, while graded silty micrite is volumetrically least important, and is restricted to the northeastern portion of the lake system.

\section{Calcareous sandstone and shale}

The calcareous sandstone and shale facies consists of pale maroon finegrained sandstone, calcareous mudstone, siltstone and shale. Individual beds range in thickness from a few centimeters to over $1 \mathrm{~m}$, and are laterally continuous for at least $100 \mathrm{~m}$. The mudstone and siltstone are well-indurated, burrowed, oxidized, and lack the fauna and flora found in most other Peterson lithologies. The facies is interbedded with or overlain by calcareous nodular limestone, and is interpreted as flood-plain deposition associated with fluvial systems which flowed into the basin, just prior to transgression of Lake Peterson.

\section{Nodular limestone}

At several localities, red nodular limestone is interbedded with calcareous sandstone and shale, but locally occurs stratigraphically just above the sandstone and shale facies. The nodules are composed of angular sandy and silty micrite clasts that have a clotted texture in hand specimen, and are cemented

B. Thin-section of graded silty micrite. Note the variation in thicknesses of individual laminations. The central lamination is nearly $2 \mathrm{~cm}$ thick, and contains several allochthonous micritic clasts of Peterson Limestone. Irregularly shaped, spar-filled voids are common.

C. Thin-section of a biomicrite, showing abundant charophyte gyrogonites and a few calcified charophyte stems in cross-section. Stem debris and gyrogonites are now spar-filled and appear dark in contrast to the siliceous carbonate mud matrix.

D. Thin-section of a biomicrite with abundant molluscan and ostracodal skeletal fragments. Note the single round charophyte gyrogonite.

$E$ and $F$. Scanning electron photomicrographs showing microfabric of the matrix comprising much of the Peterson Limestone. Note the absence of terrigenous grains and the porous three-dimensional network of diagenetic crypto-crystalline quartz. These two samples were prepared by complete leaching in strong acid to remove all calcite and secondary dolomite. Dolomite occupied the large rhombic voids and calcite occupied the smaller anhedral voids prior to treatment with acid. 
by either length-fast chalcedony, megaquartz, or sparry calcite (Fig. 2F). They resemble nodules which occur in some modern soils near the water table (Brewer, 1964), and are also similar to paleosol nodules reported from southern France (Freytet, 1973). Carbonate muds, when supporting vegetation in an oscillating water table, frequently alter to limestone nodules through remobilization and concentration of carbonate, followed by the development of fissures from repeated wetting and drying (Freytet, 1973). The nodular facies within the Peterson Limestone is interpreted as an expression of paleosol development from original carbonate-rich sediments deposites on the flood plain previously described.

\section{Sandy micrite}

Pink sandy micrite is present everywhere near the base of the Peterson Limestone above the flood plain and paleosol units, and also is present just below the base of the Bechler Formation, above micrite and biomicrite beds deposited in Lake Peterson. The units are bioturbated, and have an open framework of poorly sorted terrigenous quartz and feldspar grains that constitute from $10 \%$ to $30 \%$ of the facies. In addition to containing less terrigenous material than underlying units, this facies exhibits a less-oxidized, less-mottled fabric than underlying subaerially deposited units. These two features indicate that the micrite was deposited subaqueously in shallow nearshore areas of Lake Peterson. As the lake expanded, water depths increased, resulting in a decrease in the influx of terrigenous sand and the establishment of less oxidizing conditions.

\section{Biomicrite}

Biomicrite that lies gradationally above the lower pink sandy micrite facies comprises most of the Peterson Limestone. Individual beds range from tan to dark gray, are dense and internally structureless, resistant, range from less than $1 \mathrm{~m}$ to more than $6 \mathrm{~m}$ in thickness, and extend laterally for up to several hundreds of meters. This extensively bioturbated facies is composed primarily of dolomitic siliceous carbonate mudstone, rarely contains more than $1 \%$ terrigenous silt grains, and has preserved within it floral and faunal elements that characterize the Peterson Limestone (Eyer, 1964, 1969; Mansfield, 1952). Calcified charophyte stems and gyrogonites, ostracodes, and molluscs are common throughout virtually every unit (Figs. 2C, D, E; 3C, D). Ostracodal and molluscan skeletal debris locally comprises up to $50 \%$ of some beds, but is generally less abundant. Charophyte gyrogonites are extremely abundant and can be observed in practically every limestone sample. These hollow spheres are commonly filled with sparry calcite (Fig. 3C, D) but are also rarely silicified. Molds of charophyte stem fragments are identifiable in some thin-sections and polished slabs, but most have been crushed beyond recognition during compaction. 
Shale units, usually less than $1 \mathrm{~m}$ thick, are commonly interbedded with biomicrite beds. They contain only slightly less carbonate than the limestone, and despite their fissility, are not composed of large quantities of finegrained detrital sediment. The terrigenous fraction within these beds is of predominantly silt-sized quartz and feldspar grains, with minor amounts of chlorite and montmorillonite. Periodically increased terrigenous influx into the lake may have produced these interbedded shales by increasing the ratio of silty clay to carbonate. However, individual shale units are continuous, widespread, maintain uniform thicknesses over long distances, and do not grade laterally or vertically into more sandy terrigenous units, which would be expected from occasional influxes of non-carbonate material. Rather, their continuity and composition suggest that the shale units originated either through periods of decreased carbonate production, or through periods of increased dissolution of carbonate sediments in deeper-water parts of the lake. Climatically unfavorable conditions such as cooler mean annual temperatures would have reduced the rate of carbonate precipitation within the lake, causing a relative concentration of terrigenous material that would normally be diluted throughout the limestone. Likewise, carbonate sediments settling into deeper, cooler waters probably underwent partial dissolution, a common feature in many modern lacustrine systems. As is likely, periods of higher rates of basin subsidence increased dissolution of carbonate settling to the center of the lake basin, and the apparent concentration of terrigenous sediment.

\section{Graded silty micrite}

The graded silty micrite facies consists of fining-upward laminations that occur in beds restricted to a series of outcrops that stretch approximately 20 $\mathrm{km}$ along the northeastern margin of the lake basin (Fig. 1, sections $3,4,5$ and 6 ), and are absent from portions of the formation that exist to the southwest. Individual laminations range in thickness from less than $1 \mathrm{~mm}$ to more than $1 \mathrm{~cm}$, and are composed of sand- to silt-sized detrital quartz and feldspar-rich micrite that grades upward into more pure carbonate mudstone (Figs. 3A, B; 4). Rarely, clasts of locally derived Peterson biomicrite and broken shell material are found within the basal coarse-grained part of each lamination. All of the contacts between individual laminae are sharp and erosional. Many are wavey, and display convolute bedding, microflame structures, and microloadcasts.

The amount of carbonate in samples taken from thicker graded units commonly varies systematically in individual laminae, but the change is not in the same direction in all laminae. The amount of carbonate increases upward through some units (Fig. 5A, B), decreases upward through others (Fig. 5C, D), and shows little variation instill others. These trends are the result of variation in the relative amounts of carbonate and insoluble terrigenous material that was deposited during any one sedimentation event. Those with 

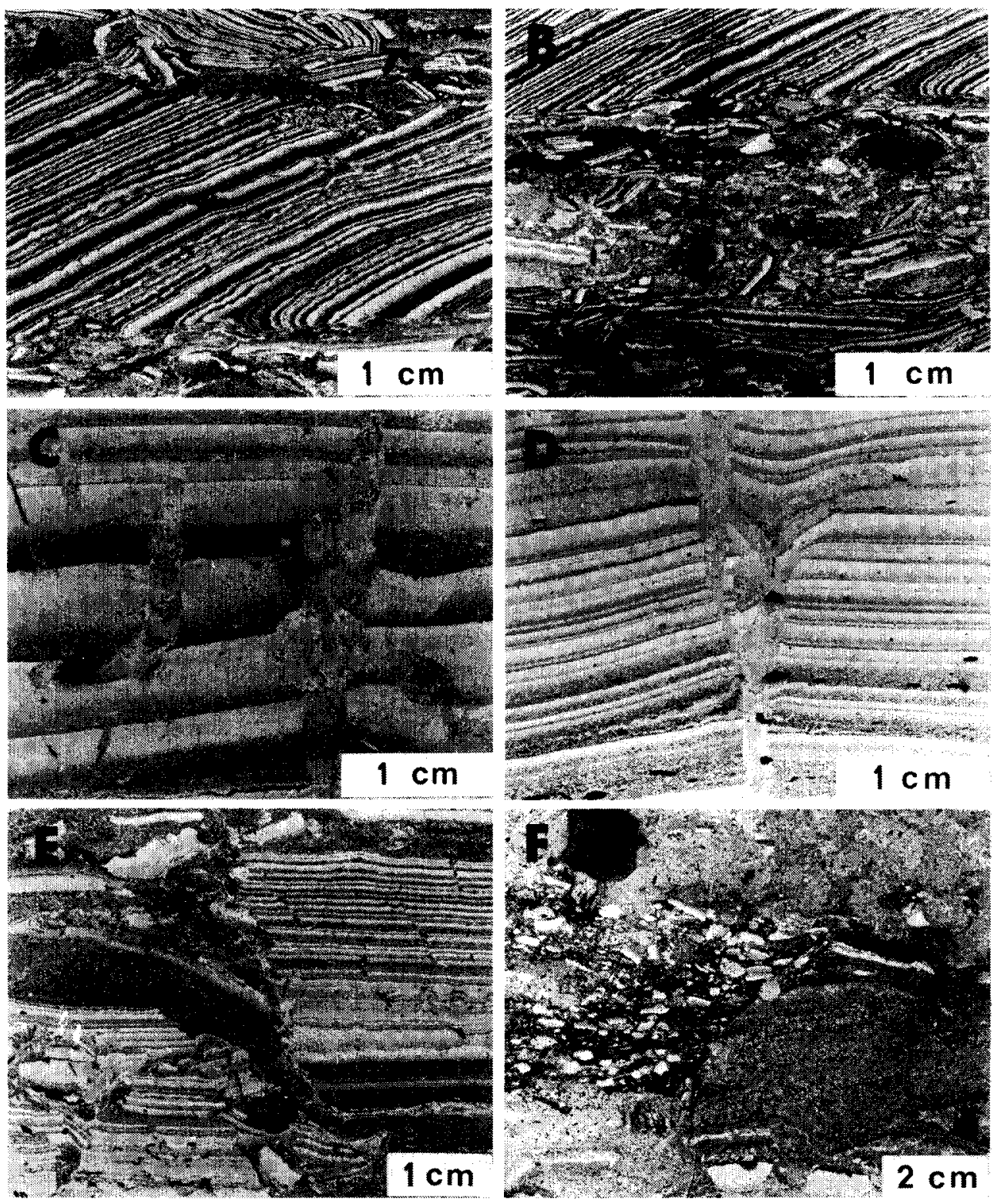

Fig. 4. Etched slabs showing deformation during gravity slumping of semi-cohesive sediment originally comprising the graded silty micrite facies.

A. Tilted block of graded laminations inclined to bedding which parallels the long dimension of this photograph. Note the curved laminae at base of the block, demonstrating that movement was from right to left. Sixty-eight laminae are seen in this view of the inclined block.

B. Base of the tilted block shown in A. The central area consists of highly deformed and broken laminations, underlain by a series of slightly less sheared but faulted laminations. 
larger amounts of insoluble material (primarily silt-size quartz and feldspar grains) concentrated at the base, exhibit increasing amounts of carbonate content upward through the lamination. Those laminations in which smaller amounts of insoluble material and larger amounts of allochthonous carbonate were concentrated in the base, exhibit a decreasing carbonate content vertically. The diagenetic microcrystalline quartz matrix (previously described), commonly present in this facies, accounts for the $30 \%-35 \%$ noncarbonate material in the uppermost parts of each lamination, and is not detrital grains (Fig. 5).

Soft-sediment gravity slumping during deposition of successive units is demonstrated by the common abrupt lateral termination of rhythmic sequences along outcrops and locally, by their highly deformed character (Fig. 4). Slumping of soft sediment, and associated gravity deformation, often results in severe disorientation of laminae, sometimes obliterating any original bedding (Fig. 4F). Penecontemporaneous microfaults, slump structures, and shear zones are ubiquitous expressions of deformation within these rocks (Fig. 4E). Wedge-shaped features, commonly resembling burrows in cross-section, are soft-sediment pull-apart structures (Fig. 4D). In plan view, they are elongate cracks that have resulted from downslope movement of blocks of semi-cohesive material. Burrows are locally preserved, but are not common in this facies (Fig. 4C). Blocks of laminated material several centimeters in length have also been observed inclined to the primary bedding. These also originated through gravity sliding, as indicated by curved laminae at the base of the tilted blocks (Fig. 4A, B). Rarely, segments of individual laminations become completely overturned during shearing deformation and now exhibit reversed grading within individual laminae.

Geographic and stratigraphic occurrence, texture, composition, and associated sedimentary structures indicate that these laminations were deposited by turbid waters carrying terrigenous silt and carbonate mud from. shallow lake margin areas toward deeper parts of the lake basin.

This deformation presumably accompanied emplacement of the overlying inclined sequence.

C. Burrows within a graded micrite sequence. Burrows are not common in this facies, and are rarely preserved.

D. Wedge-shaped pull-apart structures which resemble burrows. In plan view, these structures are elongate vertical cracks, which developed through slumping of soft sediment. Note that subsequent laminations are draped into the larger wedge, and were subsequently cut during continued crack development.

E. A faulted sequence of graded laminae. Note severe deformation along the fault plane and numerous microfaults in the laminated section in the righthand part of the photograph.

F. Deformation of this sequence has resulted in disorientation of laminae almost beyond recognition of original bedding. Note that as deformation reaches this level, fragments begin to resemble the conglomerate clasts illustrated in Fig. $2 \mathrm{~A}$ and $\mathrm{B}$. 

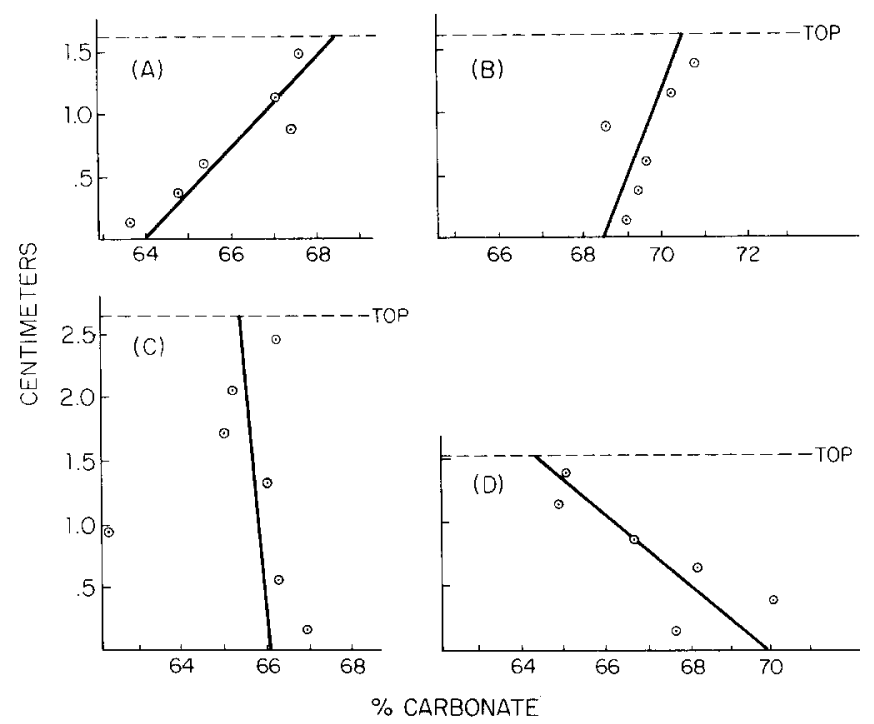

Fig. 5. Graphs illustrating the carbonate content vertically through four graded silty micrite units as determined for samples in individual laminations. A and B show increasing carbonate content; $\mathrm{C}$ and $\mathrm{D}$ show decreasing carbonate content. The compositional trends demonstrate variation in relative amounts of carbonate and insoluble terrigenous material deposited during the formation of each lamination.

\section{Limestone conglomerate}

The coarse limestone conglomerate facies corresponds to the graded silty micrite facies in its aerial distribution, whereas finer-grained conglomeratic clasts are found throughout much of the Peterson Limestone. Although not volumetrically abundant, this facies is important in interpreting processes in the lake system. The conglomerate contains mud-supported allochthonous clasts of Peterson rock types derived from within the lake basin, and occurs in units usually less than $2 \mathrm{~m}$ in thickness interbedded with biomicrites. The clasts are subangular to rounded, and are distinct in color, fossil content, and diagenetic quartz content from the carbonate mudstone matrix in which they occur (Fig. 2A, B). Both clasts and matrix exhibit the same flora and fauna, but clasts contain a greater quantity of molluscan and ostracodal shell debris, and a greater abundance of charophyte gyrogonites. In addition, matrix material contains considerably higher concentrations of diagenetic microcrystalline quartz than do the clasts. The framework of this clast-matrix association is open, resembling diamictites from many non-carbonate sequences.

Sediment comprising the conglomeratic clasts was transported, perhaps some considerable distance, within the lake system after initial deposition. These clasts do not comprise a locally derived flat-pebble conglomerate that 
typically forms in high-energy, shallow-water environments. Lower diagenetic quartz content, more abundant charophyte debris in the clasts, and nearly spherical shape indicate that they were derived from sediment initially deposited in shallow water near the lake edge. Through downslope movement by gravity sliding, slumping, or subaqueous debris flows, this semi-cohesive material was broken and rounded during transport, and subsequent deposited in finer-grained, less fossiliferous, siliceous carbonate muds.

Isolated terrigenous chert, quartzite, and limestone dropstones are locally associated with these conglomeratic units. These pebbles are up to $6 \mathrm{~cm}$ in diameter, are well-rounded, and occur suspended in fine-grained carbonate mudstone that is totally devoid of other terrigenous material (Fig. 2A). The dropstones are of the same rock type, shape, and size as pebbles found within underlying Ephriam conglomeratic units, indicating that they were originally fluvially transported and deposited near the lake's margin. However, the lack of any other associated terrigenous clasts within the same Peterson beds indicates that these were not deposited by fluvial processes in the Peterson lake sediments, nor by a process of gravity sliding or slumping similar to that which produced the associated limestone conglomerate. A reasonable mechanism for deposition of these allochthonous clasts is lakeward transport and dropping into a fine-mud bottom by either ice or floating plant material. Ice-rafting of similar clasts is known from many modern temperate-region lakes. However, even though the paleolatitude of the region was $50^{\circ}$ north during earliest Cretaceous (Van der Voo and French, 1974), cold-blooded reptiles that today do not live in temperate regions have been found in coeval formations in the Wyoming area (Mirsky, 1962; Furer, 1970). Floating plants are also known to be capable of transporting coarse-grained terrigenous material into lakes, but with the exception of algal charophytes, no plant fragments have been observed in the Peterson Limestone.

\section{DISCUSSION}

Interpretation of the processes responsible for the deposition of ancient lacustrine carbonate sequences is limited by a paucity of information about analogous modern systems. Nevertheless, several generalizations concerning the depositional processes within Lake Peterson can be inferred from the nature of the sediments that accumulated in this basin. These are schematically summarized in Fig. 6, a paleogeographic reconstruction of the area near the end of Lake Peterson time.

\section{Lake Peterson}

Based on the aerial distribution of outcrops, the lake in which the Peterson Limestone was deposited covered at least $20,000 \mathrm{~km}^{2}$. The actual extent was considerably larger, since exposures are largely confined to the overthrust belt and have undergone considerable crustal shortening. Disregarding 


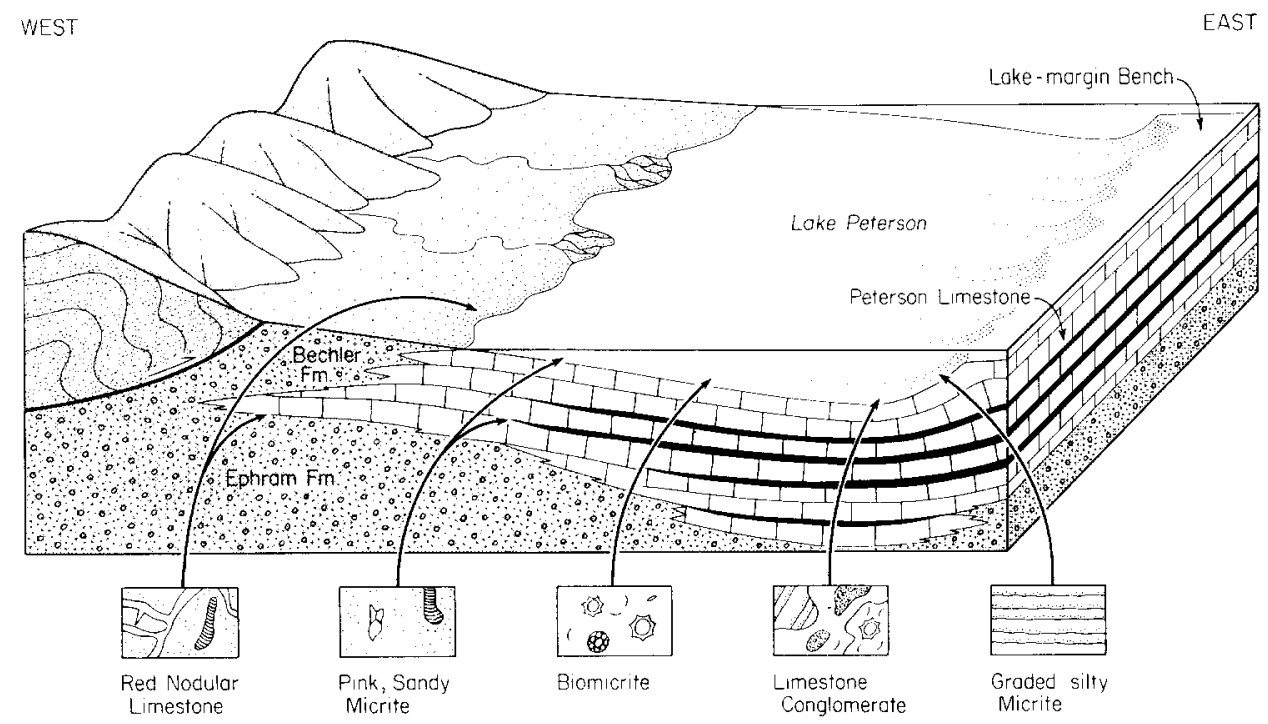

Fig. 6. Paleogeographic reconstruction of Lake Peterson showing the distribution of important rock types. Note that the Peterson is a transgressive-regressive sequence, underlain by the Aphriam Formation, and overlain by the Bechler. The Paris thrust is shown at the base of the Paleozoic highlands to the west.

this tectonic overprinting, Lake Peterson was probably comparable in size to Lake Maracaibo in Venezuela, or about twice as large as the Great Salt Lake in Utah.

The source of the carbonate that now constitutes most of this sequence was Paleozoic limestone and dolomite formations which were uplifted along the Paris thrust to the west. The abundance of carbonate in this source area is demonstrated not only by the predominance of limestone and dolomite in Paleozoic formations in this region, but also by the volumetric importance of carbonate clasts in coarser units of the underlying Ephriam and overlying Bechler formations. Chemical weathering of these Paleozoic rocks, along with abrasion and dissolution of derived clasts during transport, probably raised concentrations of both calcium and carbonate ions of inflowing waters to near saturation. The fact that the Peterson Formation is limestone rather than a more terrigenous lacustrine sequence is probably directly related to the abundance of carbonate exposed in the source area of inflowing streams.

Distribution of facies within the Peterson Limestone indicates a lake basin floor only moderately deep over most of its aerial extent, and strongly asymmetric with regard to the areas of maximum depth. Deepest-water conditions are indicated by the graded silty micrite and diamictic limestone conglomerate facies, both of which were deposited at the base of what must have been a relatively steep lake-margin slope along the eastern side of the basin. The 
original sediment which now comprises both conglomeratic clasts and individual graded laminations was derived from nearshore areas along the eastern lake shore and transported basinward by gravity slumping and turbid currents, respectively. In contrast, the western and central parts of the basin developed a relatively flat, eastward-sloping floor inclined toward the deeper parts of the lake. It is only on this surface that the bulk of the Peterson Limestone, biomicrite, accumulated.

As with many sedimentary carbonate systems, the relative importance of biochemical versus physiochemical precipitation is difficult to evaluate. Physiochemical precipitation in lacustrine systems has been documented from several areas, and appears to be most important in lakes which either experience seasonally high rates of evaporation compared to rates of inflow from surrounding streams (such as playa lakes), or experience large changes in surface temperature due to extreme seasonality of climate. Sedimentation induced by either of these annual processes is frequently recorded as varved couplets in the lake sequence, where varve composition is related to the particular mechanism causing precipitation. Although graded silty micrite laminations found in the Peterson Limestone bear a striking resemblance to varved sediment formed by these processes, their composition and structure demonstrate that they originated through physical rather than chemical processes. Some non-varved carbonate may have originated through physical precipitation in Lake Peterson, but such processes were not recorded in any of the units examined.

On the contrary, the mechanisms responsible for calcite precipitation in Lake Peterson appear to have been largely biochemical. The abundance of charophyte gyrogonites preserved throughout much of the Peterson indicates that stands of this algae probably grew over much of the lake floor, with the possible exception of the deeper portions along the eastern margin. In modern hardwater lakes charophyte algae become thickly encrusted with calcite, especially during the summer months when water temperatures are warmest and rates of photosynthesis are highest. With time, both stem encrustations and calcified gyrogonites accumulate on the lake floor, with stem encrustations comprising the bulk of the sediment. In contrast, Peterson units exhibit abundant gyrogonites, but only rarely are stem encrustations encountered in the rock. By analogy, the bulk of the calcite which was deposited on the floor of Lake Peterson was stem material which subsequently disintegrated to calcite mud during compaction and burial, leaving gyrogonites as the major identifiable algal remains.

Water depths and temperatures are parameters that are the most difficult to evaluate in ancient lacustrine systems. Although shale units within the Peterson Limestone suggest that parts of the lake basin were periodically sufficiently deep and cool to cause the dissolution of settling carbonate mud, several lines of reasoning indicate that the lake was generally relatively shallow, especially in comparison to many modern lakes of comparable size. Large deep, temperate-region lakes normally have thick epilimnions which 
are too cool to develop a thin zone of warm surface water nearly saturated with calcium carbonate during summer months, a requirement that must be satisfied for any significant production of calcareous sediment (Kindle, 1929). Most important, the extreme abundance of charophytes both vertically and horizontally within the Peterson Limestone suggests moderately shallow water, because modern lacustrine charophytes are most commonly found growing in depths that do not exceed $10 \mathrm{~m}$. Only in those facies interpreted as representing deepest-water conditions (graded silty micrite, and limestone conglomerate) are charophyte remains notably lacking.

\section{Comparison with playa lakes}

The environment of Lake Peterson can be further evaluated by analogy with two distinctly different types of modern carbonate-precipitating systems, playa lakes and temperate-region marl lakes. Modern playas are widespread throughout the southwest, and appear to be well represented as numerous Tertiary lacustrine sequences throughout the western United States (Feth, 1964). Good examples of ancient lacustrine systems which at least in part fit an evaporitic lake model are the Jurassic Todilto Formation in New Mexico (Anderson and Kirkland, 1960), and parts of the Eocene Green River Formation in Wyoming and Utah (Eugster and Surdam, 1973; Wolfbauer and Surdam, 1974; Eugster and Hardie, 1975; Surdam and Wolfbauer, 1975). Carbonate deposited in such settings is almost always impure, containing significant quantities of clay, and commonly occurs with stromatolitic structures, dolomite, and more evaporitic facies such as gypsum, halite, and other soluble salts. These units also display evidence of frequent subaerial exposure, and deposition on muddy flats under exceedingly shallow conditions. Such so-called "playas" do not serve as a good analogy to the Peterson system, which exhibits no features indicative of periodic drying, deposition on shallow mud flats, or coprecipitation of evaporite minerals.

\section{Comparison with marl lakes}

Another type of lacustrine system in which significant quantities of carbonate are being deposited occurs in temperate and subtropical regions. Although the term has been used to describe a variety of lithologies, carbonate deposits in these systems are frequently referred to as marl. Carbonate deposition in temperate regions is primarily through biochemical precipitation of low-Mg calcite during warming of surface waters and the onset of summer stratification accompanied by the loss of $\mathrm{CO}_{2}$ (Wetzel, 1970, 1975; White and Wetzel, 1975). The photosynthetic activity of charophytes and phytoplankton is primarily responsible for this spring and summer carbonate deposition. Carbonate deposits associated with marl lakes of the midwestern United States occur as broad platforms or benches extending from the lake shore basinward, to water depths of approximately $1 \mathrm{~m}$. At the plat- 
form edge there is commonly an abrupt break in slope where the lake bottom becomes steeply inclined and descends basinward to depths of $25 \mathrm{~m}$ or more, attaining angles up to $39^{\circ}$ (Hooper, 1956). Most of the carbonate deposited within these systems is internally structureless and unbedded, but algal pisoliths frequently form on platform surfaces in water depths up to several meters. These lakes are dimictic, and contain well-oxygenated bottom waters where fine-grained carbonate mud accumulates along with debris of molluscs and ostracods. Charophytes are the most abundant floral element within these systems. Both stem encrustation and gyrogonites make up the bulk of the carbonate within marl lakes.

The similarity of lithologic, faunal, and floral features of these lake sediments and those of Peterson deposits, make marl lakes an attractive analogy to Lake Peterson. Further, slopes on modern marl benches are similar to those required for turbidite and diamictic conglomerate generation, while the deeper, cooler hypolimnic waters of the temperate-region systems may be analogous to those which periodically occupied the deeper parts of Lake Peterson causing carbonate dissolution and shale deposition. However, the comparisons between the two systems are not perfect because pisoliths, which are a diagnostic shallow-water structure in marl lakes, are unreported from Peterson sections.

Although several features of Lake Peterson are difficult to evaluate by either examination of component facies or by comparison with modern lake systems, a lake basin of considerable size, exhibiting many similarities to temperate-region marl lakes, seems best to fit the features displayed by this ancient lacustrine carbonate sequence.

\section{ACKNOWLEDGEMENTS}

We thank John A Dorr, Jr., Charles I. Smith, and Franklyn B. van Houten for reading the original manuscript and making helpful suggestions. Portions of this study were financed from a Scott Turner Earth Sciences Award from the Department of Geology and Mineralogy, The University of Michigan, and a Grant-in-Aid of Research from Sigma Xi. The assistance of David N. Murphy for chemical analyses is gratefully acknowledged. Drafting was done by Derwin Bell.

\section{REFERENCES}

Anderson, R.Y. and Kirkland, D.W., 1960. Origin, varves, and cycles of Jurassic Todilto Formation, New Mexico. Am. Assoc. Pet. Geol. Bull., 44 (1): 37-52.

Armstrong, F.C. and Oriel, S.S. 1965. Tectonic development of the Idaho-Wyoming thrust belt. Am. Assoc. Pet. Geol. Bull., 49 (11): 1847-1866.

Brewer, R., 1964. Fabric and Mineral Analysis of Soils. Wiley, New York, N.Y., 470 pp.

Eugster, H.P. and Hardie, L.A., 1975. Sedimentation in an ancient playa-lake complex: the Wilkins Peak Member of the Green River Formation of Wyoming. Geol. Soc. Am. Bull., 86: 319-334. 
Eugster, H.P. and Surdam, R.C., 1973. Depositional environment of the Green River Formation of Wyoming: a preliminary report. Geol. Soc. Am. Bull., 84: 1115-1120.

Eyer, J.A., 1964. Stratigraphy and Micropaleotology of the Gannett Group of Western Wyoming and Southeastern Idaho. Ph. D. diss., Univ. Colorado, 151 pp. (unpublished).

Eyer, J.A., 1969. Gannett Group of western Wyoming and southeastern Idaho. Am. Assoc. Pet. Geol. Bull., 53 (7): 1368-1391.

Feth, J.H., 1964. Review and annotated bibliography of ancient lake deposits (Precambrian to Pleistocene) in the western United States. U.S.G.S. Bull., 1080: 119 pp.

Freytet, P., 1973. Petrology and paleo-environment of continental deposits with particular reference to the Upper Cretaceous and Lower Eocene of Languedoc (southern France). Sediment. Geol., 10: 25-60.

Furer, L.C., 1970. Petrology and stratigraphy of nonmarine Upper Jurassic-Lower Cretaceous rocks of western Wyoming and southeastern Idaho. Am. Assoc. Pet. Geol. Bull., 54 (12): $2282-2302$.

Holm, M.R., 1977. Comparison of the Peterson and Draney limestones (Lower Cretaceous), Idaho and Wyoming, and the Calcareous Members of the Kootenai Formation, Western Montana. Master Thesis, Indiana Univ., 68 pp. (unpublished)

Hooper, F., 1956. Some chemical and morphometric characteristics of southern Michigan lakes. Pap. Mich. Acad. Sci. Arts Lett., 51: 109-130.

Kauffman, E.G., 1977. Geological and biological overview: western interior Cretaceous basin. The Mountain Geologist, 14 (3/4): 75-99.

Kindle, E.M., 1929. A comparative study of different types of thermal stratification in lakes and their influence on the formation of marl. J. Geol., 37: 150-157.

Love, J.D., 1956. Cretaceous and Tertiary stratigraphy of the Jackson Hole area, northwestern Wyoming. Wyo. Geol. Assoc. Guidebk., 11th Annu. Field Conf., pp. 76-94.

Love, J.D., Duncan, D.C., Bergquist, H.R. and Hose, R.K., 1948. Stratigraphic sections of Jurassic and Cretaceous rocks in the Jackson Hole area, northwestern Wyoming. Geol. Surv. Wyo. Bull., 40: 48 pp.

Mansfield, G.R., 1952. Geography, geology, and mineral resources of the Ammon and Paradise Valley Quadrangles, Idaho: U.S.G.S. Prof. Pap., 238: 91 pp.

Mansfield, G.R. and Roundy, P.V., 1916. Revision of the Beckwith and Bear River Formation of southeastern Idaho. U.S.G.S. Prof. Pap., 98: 75-84.

Mirsky, A., 1962. Stratigraphy of non-marine Upper Jurassic and Lower Cretaceous rocks, southern Big Horn Mountains, Wyoming. Am. Assoc. Pet. Geol. Bull., 46 (9): 1653-1680.

Surdam, R.C. and Wolfbauer, C.A., 1975. Green River Formation, Wyoming: a playa lake complex. Geol. Soc. Am. Bull., 86: 335-345.

Van der Voo, R. and French, R.B., 1974. Apparent polar wandering for the Atlanticbordering continents: Late Carboniferous to Eocene. Earth Sci. Rev., 10: 99-119.

Wetzel, R.G., 1970. Recent and post-glacial production rates in a marl lake. Limnol. Oceanogr., 15: 491-503.

Wetzel, R.G., 1975. Limnology. W.B. Saunders.

White, W.S. and Wetzel, R.G., 1975. Nitrogen, phosphorous, and colloidal carbon content of sediment seston of a hard-water lake. Verh. Int. Ver. Limnol., 19: 330-339.

Wolfbauer, C.A. and Surdam, R.C., 1974. Origin of nonmarine dolomite in Eocene Lake Gosiute, Green River Basin, Wyoming. Geol. Soc. Am. Bull., 85: 1733-1740. 